\title{
Efektivitas Model Pembelajaran Problem Based Learning terhadap Kemampuan Literasi Ekologi Siswa Kelas X Sekolah Menengah Atas
}

\author{
Latif Agung Nugroho ${ }^{1 *}$, Baskoro Adi Prayitno ${ }^{2}$, Puguh Karyanto ${ }^{3}$ \\ ${ }^{123}$ Universitas Sebelas Maret \\ $\sqsubseteq$ e-mail: elbk1991@gmai.com
}

\begin{abstract}
Abstrack
The purpose of the study is investigating the effect of problem based learning on students' ecological literacy, comparing problem based learning with traditional teaching method. Quasi experimental research design included 60 students (30 experimental, 30 control group) in 10 grade senior high school in Surakarta. The experimental group was taught using the problem based learning while the control group was taught using the traditional approach. The control and the experiment group have been determined randomly. The data were collected using ecological literacy scale. The data has been analyzed by using statistical analysis techniques. Independent sample t-test was used for data analysis with SPSS 18.0. The results of the study showed that the problem based learning method was more effective in improving the ecological literacy skills of students compared to the traditional method.
\end{abstract}

Keyword: problem based learning, traditional teaching method, ecological literacy.

Copyright (C) 2018 IICET (Indonesia) - All Rights Reserved

Indonesian Institute for Counseling, Education and Therapy (IICET)

\section{PENDAHULUAN}

Perkembangan pembangunan di berbagai sektor yang semakin pesat mengakibatkan masalah kerusakan lingkungan dan degradasi ekosistem dalam satu dekade ini (Ginkel, 2007). Faktor terpenting dalam permasalahan lingkungan adalah besarnya populasi manusia (laju pertumbuhan penduduk). Pertumbuhan penduduk yang pesat menimbulkan tantangan yang dicoba diatasi dengan pembangunan dan industrialisasi. Namun industrialisasi disamping mempercepat persediaan segala kebutuhan hidup manusia juga memberi dampak negatif terhadap manusia akibat terjadinya pencemaran lingkungan (Mahdi et al, 2009).

Masalah lingkungan yang semakin banyak menimbulkan berbagai pertanyaan mengenai penyebab terjadinya masalah tersebut. Goldman (2009) dan Ibrahim (2016) menyatakan bahwa kerusakan lingkungan yang semakin banyak disebabkan oleh kurangnya kecerdasan ekologis yang dimiliki oleh setiap atau sebagian individu yang berada di suatu wilayah tertentu sehingga menumpulkan kepekaan terhadap tanda-tanda kerusakan alam (Gardner, 2006; Gould \& Hosey, 2006).

Tingkat literasi ekologi siswa yang kurang menimbulkan pertanyaan tentang penyebab rendahnya literasi ekologi siswa. Untuk mengetahui penyebabnya, dilakukan observasi mengenai implementasi kurikulum dan pembelajaran di kelas yang meliputi model pembelajaran, keaktifan siswa, cara guru melaksanakan proses 
pembelajaran dan sumber belajar yang digunakan. Pengumpulan data awal menggunakan instrumen pedoman wawancara dan observasi.

Hasil wawancara dan observasi tentang kurikulum, melalui analisis deskriptif kualitatif menunjukkan bahwa kurikulum mata pelajaran biologi menggunakan kurikulum 2013. Secara garis besar materi ekosistem yang disampaikan antara lain komponen ekosistem, tipe ekosistem, aliran energi daur biogeokimia. Komponen yang ada dalam literasi ekologi yaitu knowledge, concern dan attitude belum mendapat perhatian yang sama dalam pencapaiannya. Komponen yang berkaitan dengan pengetahuan sangat ditekankan, sedangkan komponen yang lain hanya sebagian. Oleh karena itu, perlu adanya evaluasi terhadap implementasi kurikulum yang berkaitan dengan penilaian literasi ekologi. Seharusnya semua komponen yang termasuk dalam penilaian literasi ekologi sama-sam diperhatikan baik penilaian kognitif, concern dan attitude.

Kegiatan pembelajaran yang diobservasi menggunakan instrumen lembar observasi, kemudian dianalisis melalui deskriptif kualitatif. Hasil analisis menunjukkan bahwa Guru belum maksimal dalam mengaplikasikan berbagai model pembelajaran yang bisa diterapkan di kelas. Guru lebih cenderung menyampaikan materi pelajaran satu arah (teacher centered). Pembelajaran yang bersifat teacher centered akan sangat sulit untuk mengembangkan keaktifan siswa, sehingga kemampuan literasi ekologi siswa pun akan cenderung kurang maksimal untuk ditingkatkan. Hal ini sesuai dengan hasil survei kemampuan literasi ekologi siswa SMA N 7 Surakarta yakni komponen knowledge memiliki rata-rata 60, concern 69 dan attitude 60. Hasil tersebut menunjukkan tingkat literasi ekologi siswa masih tergolong kurang berdasarkan penelitian yang dilakukan Pitman dan Daniels tahun 2016. Oleh karena itu, perlu untuk mengaplikasikan model pembelajaran yang bisa untuk membuat siswa aktif dan antusias dalam mengikuti pembelajaran yang diharapkan kemampuan literasi ekologi siswa bisa ditingkatkan.

Hasil wawancara terhadap siswa, mereka antusias dalam pembelajaran biologi. Terkadang guru membawakan pembelajaran dengan menarik seperti presentasi, kuis atau pembelajaran berbasis komputer. Akan tetapi, sebagian besar guru sering menyampaikan materi dengan ceramah. Mereka menginginkan pembelajaran yang menarik, bervariasi. Sedangkan hasil wawancara terhadap guru, bahwa guru mapel biologi ingin menyampaikan materi dengan model pembelajaran yang bervariasi, akan tetapi keterbatasan waktu yang masih sulit untuk diatasi. Selain itu mereka berpendapat bahwa bahan ajar (buku paket) dilihat dari konten materi, lembar kerja siswa dan uji kompetensi yang digunakan belum cukup untuk bisa meningkatkan literasi ekologi siswa. Hasil observasi dan wawancara di atas, menunjukkan bahwa model pembelajaran, buku ajar dan media yang digunakan dalam pembelajaran biologi materi ekosistem belum bisa meningkatkan literasi ekologi siswa.

Dalam rangka meningkatkan literasi ekologi melalui pendidikan di sekolah, mempunyai alasan kuat yang terletak pada karakteristik yang dimiliki oleh sektor pendidikan. Pendidikan mempunyai karakteristik sebagai proses yang akan menghasilkan perubahan dalam ranah kognitif, peningkatan kompetensi (keterampilan), serta pemilihan dan penerimaan secara sadar terhadap nilai, sikap, serta kemauan untuk merepon suatu rangsangan (Gage \& Berliner, 1983; Karyanto et al, 2014). Kelebihan dari karakteristik pendidikan tersebut menjadikan pendidikan sebagai salah satu strategi untuk mengubah perilaku masyarakat dalam berinteraksi dengan lingkungan dan sumber daya melalui upaya mengarahkan pada cara pandang yang positif terhadap lingkungan (Karyanto et al,2014).

Pendidikan yang merupakan strategi untuk mengarahkan perubahan cara pandang, tingkah laku yang positif terhadap lingkungan tentunya memunculkan tantangan yang besar dalam pencapaian hasil pembelajaran, yaitu mengenai efektivitas proses pembelajaran yang berlangsung dalam rangka menghasilkan sikap dan perilaku yang diharapkan. Tolok ukur dari efektivitas proses pembelajaran merupakan hal penting yang dapat digunakan sebagai indikator ketercapaian hasil belajar yang ditetapkan. Efektivitas proses pembelajaran dapat diukur melalui pemilihan pendekatan, strategi dan model pembelajaran yang efektif (Ong 
and Borich, 2006; Karyanto et al, 2014). Pemilihan pendekatan, strategi dan model pembelajaran yang efektif untuk mencapai tujuan tersebut cukup banyak. Model pembelajaran yang di pandang dapat menjamin efektivitas tersebut adalah pendekatan, strategi atau model pembelajaran yang bermakna (Ellis et al; Wahab, 2009). Pembelajaran bermakna akan terwujud apabila menerapkan pembelajaran dengan pendekatan saintifik (Kurniasih, 2014). Model pembelajaran dengan pendekatan saintifik sesuai dengan kurikulum 2013 antara lain discovery learning, inquiry learning, project dan problem based learning. Salah satu model pembelajaran yang menggunakan pendekatan saintifik adalah model problem based learning (PBL).

Problem based learning merupakan model pembelajaran yang bercirikan adanya permasalahan nyata sebagai konteks untuk para peserta didik belajar berfikir kritis, memecahkan masalah, dan memperoleh pengetahuan (Schaefer, 2013). Pembelajaran berbasis masalah merupakan jawaban terhadap praktek pembelajaran kompetensi serta merespon perkembangan dinamika sosial masyarakat dan menghargai keanekaragaman masyarakat. Karakteristik PBL tersebut merupakan sebuah keunggulan dibandingkan dengan model pembelajaran yang lain dalam rangka mencapai tujuan pembelajaran untuk meningkatkan literasi ekologi. Hal ini disebabkan aspek dari literasi ekologi bersesuaian dengan karakteristik PBL. Aspek penyusun yang tercakup dalam literasi ekologi adalah aspek knowledge (berkaitan dengan membangun pemahaman konsep ekologi), aspek concern (kepedulian) dan aspek attitude (sikap) (Orr, 1992; Capra, 2007; McBride, 2011; Dajeh, 2011).

Merujuk dari penjelasan di atas, PBL berpotensi memberikan pengalaman belajar yang bermakna, yang akan memberikan penguatan pada aspek hard skill dan soft skill (Karyanto et al, 2014). Penguatan pada aspek hard skill dan soft skill tersebut dapat memberikan jaminan bahwa pendidikan yang dilaksanakan dapat menghasilkan sumber daya manusia yang berkualitas, sesuai dengan amanah undang-undang pendidikan nasional. Dengan demikian, implementasi model pembelajaran PBL diharapkan akan meningkatkan literasi ekologi siswa sekolah menengah.

\section{METODOLOGI}

Jenis Penelitian ini adalah eksperimen semu (quasi-eksperimental). Pada desain ini, kontrol atau pengendalian variabel tidak bisa dilakukan secara ketat atau secara penuh. Peneliti tidak bisa mengubah kelas siswa dalam menentukan subjek untuk kelompok-kelompok eksperimen. Penelitian ini dilaksanakan pada semester genap, yaitu bulan mei tahun ajaran 2016/2017 di SMA N 7 Surakarta.

Populasi penelitian ini adalah seluruh siswa kelas X SMA N 7 Surakarta yang terdistribusi dalam enam kelas. Teknik pengambilan sampel menggunakan cluster random sampling dan diperoleh kelas X MIPA 3 sebagai kelompok eksperimen yang mengikuti pembelajaran dengan model PBL dan kelas X MIPA 4 sebagai kelompok kontrol yang mengikuti pembelajaran dengan model pembelajaran konvensional.

Desain penelitian ini adalah pretest-posttest control group design. Berikut adalah desain penelitian:

\begin{tabular}{lccc}
\hline Kelas & Pretest & Perlakuan & Posttest \\
\hline Kontrol & $\mathrm{L}_{1}$ & $\mathrm{X}$ & $\mathrm{L}_{2}$ \\
Eksperimen & $\mathrm{L}_{1}$ & $\mathrm{Y}$ & $\mathrm{L}_{2}$ \\
\hline
\end{tabular}

Keterangan:

$\mathrm{L}_{1} \quad=$ Literasi ekologi awal

$\mathrm{X} \quad=$ Pembelajaran konvensional

$\mathrm{Y} \quad=$ Pembelajaran model PBL

$\mathrm{L}_{2} \quad=$ Literasi ekologi akhir 
Penelitian ini menggunakan intrumen penelitian berupa perangkat pembelajaran, lembar observasi, instrument tes dan angket. Perangkat pembelajaran yang digunakan adalah rencana pelaksanaan pembelajaran (silabus, RPP) dan lembar kegiatan siswa (LKS). Pembuatan silabus dan RPP disesuaikan dengan format kurikulum 2013. Ada dua jenis RPP yang dibuat yaitu RPP untuk kelompok eksperimen dengan model PBL dan RPP untuk kelompok kontrol dengan model pembelajaran konvensional. Lembar observasi digunakan untuk mengetahui keterlaksanaan pembelajaran yang dilakukan. Indikator keterlaksanaan pembelajaran dibuat berdasarkan langkah-langkah model pembelajaran yang digunakan yaitu model PBL dan model pembelajaran konvensional.

Instrumen tes literasi ekologi berupa tes tertulis dan angket. Tes tertulis berbentuk soal pilihan ganda dengan indikator yang mengacu pada konsep ekologi yang disampaikan oleh Lewinshon (2015). Tes tertulis tersebut digunakan untuk mengukur aspek knowledge dari literasi ekologi. Instrumen angket disusun untuk mengukur aspek concern dan attitude dari literasi ekologi. Angket untuk concern disusun berdasarkan indikator Al-dajeh (2012) yang berjumlah 52 pernyataan, sedangkan angket untuk attitude diadaptasi dari New Ecological Paradigm yang berjumlah 15 pernyataan (Dunlap, 2008). Angket concern dan attitude menggunakan skala likert dengan skor 1 sampai 5.

Teknik pengumpulan data dalam penelitian adalah sebagai berikut. 1) menyusun instrument-instrumen yang akan digunakan dalam proses penelitian; RPP, LKS, soal latihan dan kuis, dan soal pretest-posttest. 2) validasi Instrumen yang akan digunakan oleh dosen ahli atau validator. 3) Melakukan prasurvey serta mengajukan perijinan ke sekolah yang bersangkutan. 4) melakukan pretest kepada kedua kelompok kelas yang telah ditentukan. 5) melakukan eksperimen model pembelajaran di kelas yang menjadi objek penelitian bersama guru biologi yang bersangkutan. 6) melakukan posttest kepada kedua kelompok kelas yang telah diberi perlakuan. 7) menganalisa data yang diperoleh.

Data kemampuan literasi ekologi siswa kelompok eksperimen dan siswa kelompok kontrol dianalisis menggunakan independent sample t-test dengan bantuan software SPSS 18.0. Sebelum melakukan analisis dilakukan uji prasyarat, yaitu uji normalitas data, uji homogenitas.

Setelah dilakukan uji normalitas, diperoleh sampel berasal dari populasi yang berdistribusi normal. Dari uji homogenitas diperoleh data kemampuan literasi ekologi kedua kelas homogen.

\section{HASIL DAN PEMBAHASAN}

\section{Hasil}

Tabel 2 berikut ini menunjukkan rata-rata skor pretest kemampuan literasi ekologi siswa kelas eksperimen dan kelas kontrol.

Tabel 1. Hasil Pretest Kelas Eksperimen dan Kontrol

\begin{tabular}{clcc}
\hline No. & $\begin{array}{l}\text { Aspek penilaian } \\
\text { ekologi }\end{array}$ & literasi & \multicolumn{2}{c}{ Pretest } \\
\cline { 3 - 4 } 1. & Knowledge & Kelas eksperimen & Kelas kontrol \\
2. & Concern & 60 & 60 \\
3. & Attitude & 69 & 65 \\
& Rata-rata & 60 & 63 \\
\end{tabular}

Pada tabel di atas, hasil rata-rata pretest kemampuan literasi yang terdiri dari aspek knowledge, concern dan attitude pada kelompok eksperimen adalah 63,00, sedangkan pada kelompok kontrol 62,66. 
Tabel 3 berikut ini menunjukkan rata-rata skor posttest kemampuan literasi ekologi kelas eksperimen dan kelas kontrol.

Tabel 2. Hasil posttest kelas eksperimen dan kontrol

\begin{tabular}{clccc}
\hline No. & Aspek penilaian & literasi & \multicolumn{2}{c}{ Posttest } \\
\cline { 3 - 4 } ekologi & & Kelas eksperimen & Kelas kontrol \\
1. & Knowledge & 80 & 74 \\
2. & Concern & 81 & 72 \\
3. & Attitude & 78 & 66 \\
& $\quad$ Rata-rata & 79,66 & 70,66 \\
\hline
\end{tabular}

Pada tabel di atas, hasil rata-rata posttest kemampuan literasi yang terdiri dari aspek knowledge, concern dan attitude pada kelompok eksperimen adalah 79,66, sedangkan pada kelompok kontrol 70,66.

Hasil analisis menggunakan SPPS 18.0 diketahui bahwa data kelompok eksperimen dan kelompok kontrol berdistribusi normal, homogen dan tidak ada perbedaan rata-rata awal kemampuan literasi ekologi pada kedua kelompok sehingga analisis yang digunakan untuk menguji hipotesis adalah uji statistik dengan uji-t independent pada taraf signifikansi 0,05 atau tingkat kepercayaan 95\%. Tabel 4 berikut ini menunjukkan uji hipotesis menggunakan uji-t independent.

\begin{tabular}{cccc}
\hline Aspek & $\mathbf{t}$ & Sig. & Keputusan \\
\hline Literasi ekologi & 7.204 & 0.000 & $\mathrm{H}_{\mathrm{O}}$ ditolak \\
\hline
\end{tabular}

Berdasarkan uji hipotesis, diperoleh thitung = 7,204 > ttabel = 4,367 dan nilai signifikansi 0,000 0,05. Maka H0 ditolak atau dengan kata lain model problem based learning lebih efektif dari pembelajaran model konvensional ditinjau dari kemampuan literasi ekologi siswa.

\section{Pembahasan}

Hasil pengujian tersebut dapat memberikan kesimpulan bahwa pembelajaran model PBL lebih efektif dari model pembelajaran konvensional jika ditinjau dari kemampuan literasi ekologi. Kemampuan literasi ekologi siswa yang mengikuti pembelajaran dengan model PBL lebih baik daripada siswa yang mengikuti pembelajaran model konvensional. Hal ini dikarenakan pada pembelajaran PBL siswa dibiasakan untuk aktif berdiskusi, bekerja sama dalam kelompok, dan menyajikan hasil kegiatan diskusi ke depan kelas sehingga kemampuan literasi ekologi siswa berkembang dengan baik. Ketika siswa diberi LKS yang berisi permasalahan, siswa berusaha memecahkan masalah tersebut dengan diskusi kelompok. Siswa aktif berdiskusi dengan anggota kelompok untuk memunculkan gagasan/ide untuk menyelesaikan masalah tersebut. Siswa yang mengikuti pembelajaran model PBL dibiasakan untuk mengungkapkan pendapatnya menggunakan kalimatnya sendiri sehingga aspek concern pada siswa akan berkembang. Selain itu, siswa melakukan kegiatan penyelidikan seperti mencari informasi dari referensi (buku, teman, guru), merencanakan penyelesaian masalah, menyelesaikan masalah, dan memeriksa kembali hasil pekerjaannya. Kegiatan penyelidikan/mencari informasi dan menyelesaikan masalah akan membuat kemampuan siswa pada aspek knowledge akan berkembang. Solusi yang diberikan siswa dalam penyelesaian masalah dapat mengasah kemampuan siswa pada aspek attitude. Semua proses tersebut dapat mengakibatkan siswa berperan aktif dalam pembelajaran sehingga kemampuan literasi ekologi siswa berkembang dengan baik. Lewinshon (2015) menyatakan bahwa dalam rangka menjaga kelestarian lingkungan, setiap individu seharusnya memiliki kemampuan literasi ekologi yang mumpuni, kemampuan literasi ekologi tersebut dapat ditingkatkan melalui pembelajaran berbasis masalah.

\section{SIMPULAN DAN SARAN}


Berdasarkan hasil penelitian, maka dapat disimpulkan hasil penelitian dan analisis data adalah penggunaan model problem based learning lebih efektif dari model pembelajaran konvensional pada pembelajaran biologi materi ekositem untuk meningkatkan kemampuan literasi ekologi siswa.

Saran yang dapat disampaikan yaitu kemampuan literasi ekologi siswa sebaiknya lebih diperhatikan untuk dievaluasi. Selain itu, guru hendaknya menggunakn model pembelajaran yang bervariasi untuk membuat siswa aktif dalam pembelajaran.

\section{DAFTAR RUJUKAN}

Al-dajeh, H. L. (2011). Assessing Environmental Literacy of Pre-Vocational Education Teachers in Jordan. College Student Journal, 46(3), 492-507.

Alrahlah, A. (2016). How effective the problem-based learning (PBL) in dental education. A critical review. The Saudi Dental Journal, 28(4), 155-161. https://doi.org/10.1016/j.sdentj.2016.08.003

Arends, Richard. (2008). Learning To Teach. New York: McGraw Hill Companies

Aydin, Y. (2014). The Effects of Problem Based Approach on Student's Conceptual Understanding in a University Mathematics Classroom. Procedia - Social and Behavioral Sciences, 152 (September 2013), 704-707. https://doi.org/10.1016/j.sbspro.2014.09.307

Berkowitz, A. R., Ford, M. E., \& Brewer, C. A. (2005). A framework for integrating ecological literacy, civics literacy, and environmental citizenship in environmental education. Environmental Education and Advocacy: Changing Perspectives of Ecology and Education.

Capra, F. (2007). Sustainable living, ecological literacy, and the breath of life. Canadian Journal of Environmental Education, 12, 9-19.

Dahar, Ratna Wilis. (1996). Teori-teori Belajar. Jakarta :Erlangga.

Dunlap, R. E., Liere, K. D. Van, Mertig, A. G., \& Jones, R. E. (2000). Measuring Endorsement of the New Ecological Paradigm: A Revised NEP Scale. Journal of Social Issues, 56(3), 425-442. https://doi.org/10.1111/0022-4537.00176

Gage, N. L., \& Berliner, D. (1983). Educational Psychology. Boston: Houghton Mifflin, USA Ginkel, Hans Van. (2006). Global Efforts on Education for Sustainable Development and UNU Regional Centres of Expertise on Ef SD, Workshop on Education for Sustainable Development and the role of RCE Tongyeong, 29-30 March 2006, Tongyeong City.

Hamalik,O. (2008). Belajar dan Teori Belajar. Jakarta: Bumi Aksara.

Hamdani. (2011). Strategi Belajar Mengajar. CV Pustaka Setia: Bandung

Ibrahim, M; Nur, M. (2005). Pengajaran Berbasis Masalah. University Press: Surabaya

Karyanto, P., Prayitno, B. A., Sajidan, \& Suwarno. (2014). Penguatan Modal Manusia Dan Peningkatan Literasi Ekologi Melalui Pedagogi Spesifik Materi Pengembangan Model Dalam Pembelajaran Ekologi Melalui Penelitian Ekofisiologi Tikus Sawah. Vol 11, No 1, 602., 601-606.

Kurniasih, I., \& Sani, B. (2014). Implementasi Kurikulum 2013 Konsep dan Penerapan. Kementrian Pendidikan Dan Kebudayaan, 1-162. 
Kwan, T., \& So, M. (2008). Environmental learning using a problem-based approach in the field: $\{$ A $\}$ case study of a \{Hong\} \{Kong\} school. International Research in Geographical and Environmental Education, 17(2), 93-113. https://doi.org/10.1080/10382040802148562

Lewinsohn, T. M., Attayde, J. L., Fonseca, C. R., Ganade, G., Jorge, L. R., Kollmann, J., ... Weisser, W. W. (2014). Ecological literacy and beyond: Problem-based learning for future professionals. Ambio, 44(2), 154-162. https://doi.org/10.1007/s13280-014-0539-2

Mcbride, B. B. (2011). Essential Elements of Ecological Literacy and the Pathways to Achieve It: Perspectives of Ecologists.

Mcginn, A. E. (2014). Quantifying and Understanding Ecological Literacy : A Study of First Year Students at Liberal Arts Institutions.

Michael K. Stone. (2009). Center for Ecoliteracy, Smart by Nature: Schooling for Sustainability, Watershed Media

Noor Hisham Jalania \& Lai Chee Sernb. (2015). The Example-Problem-Based Learning Model: Applying Cognitive Load Theory. Procedia - Social and Behavioral Sciences, 195(July), 872-880. https://doi.org/10.1016/j.sbspro.2015.06.366

Ong, A \& Borich.G.D. (2006). Teaching Strategies That Promote Thinking: Model and Curiculum Approaches. Singapore: McGraw Hill.

Orr, David (1992). Ecological Literacy: Education and the Transition to a Postmodern World. $\quad$ S.U.N.Y. Press: NY.

Pe'er, S., Goldman, D., \& Yavetz, B. (2007). Environmental Literacy in Teacher Training: Attitudes, Knowledge, and Environmental Behavior of Beginning Students. The Journal of Environmental Education, 39(1), 45-59. https://doi.org/10.3200/JOEE.39.1.45-59

Pitman, S. D., \& Daniels, C. B. (2016). Quantifying ecological literacy in an adult western community: The development and application of a new assessment tool and community standard. PLoS ONE, 11(3), 119. https://doi.org/10.1371/journal.pone.0150648

Rusman. (2012). Model-Model Pembelajaran Mengembangkan Profesionalisme Guru. PT Raja Grafindo Persada

Rusmono. (2012). Strategi Pembelajaran dengan PBL itu Perlu. Ghalia Indonesia: Bogor

Sancayaningsih, R. P. (2014). Seminar Nasional X Pendidikan Biologi FKIP UNS 21, 21-24.

Schaefer, V., \& Gonzales, E. (2013). Using Problem-based Learning to Teach Concepts for Ecological Restoration. Ecological Restoration, 31(4), 412-418. https://doi.org/10.3368/er.31.4.412

Tan, Oong-Seng. (2003). Problem-Based Learning Innovation: Using Problems to Power Learning in the $21 \mathrm{st}$ Century. Cengage Learning: Singapore

UNESCO. (n.d.). World Conference on Higher Education 2009 Final Report, 81.

Winkel, W.S. (2009). Psikologi Pengajaran. Media Abadi: Yogyakarta.

Yuan, H., Kunaviktikul, W., Klunklin, A., \& Williams, B. A. (2008). Promoting Critical Thinking Skills Through Problem-Based Learning. CMU. Journal of Soc. Sci. and Human, 2(2). 